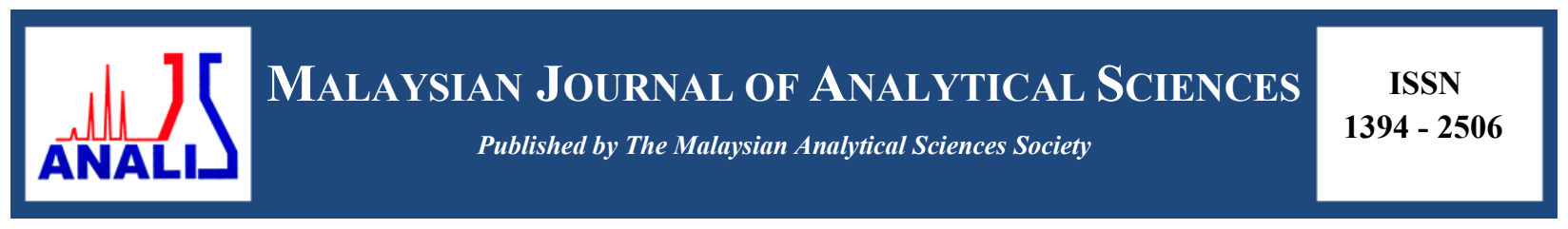

\title{
ION-CONDUCTING POLYMER ELECTROLYTE FILMS BASED ON POLY (SODIUM 4-STYRENESULFONATE) COMPLEXED WITH AMMONIUM NITRATE: STUDIES BASED ON MORPHOLOGY, STRUCTURAL AND ELECTRICAL SPECTROSCOPY
}

\author{
(Filem Elektrolit Polimer Pengaliran Ion Berasaskan Kompleks Poli(sodium 4-stirenasulfonat) \\ dengan Amonium Nitrat: Kajian ke atas Morfologi, Struktur dan Spektroskopi Elektrik) \\ Mohd Faiz Hassan*, Siti Khalijah Zainuddin, Khadijah Hilmun Kamarudin, Chan Kok Sheng, \\ Mohd Aidil Adha Abdullah \\ School of Fundamental Sciences \\ Universiti Malaysia Terengganu, 21030 Kuala Nerus, Terengganu, Malaysia \\ *Corresponding author: mfhassan@umt.edu.my
}

Received: 10 July 2017; Accepted: 12 March 2018

\begin{abstract}
Solid polymer electrolytes of poly(sodium 4-styrenesulfonate) as a polymer host and ammonium nitrate as an ionic dopant were prepared using a single-solvent via solution casting technique. According to the X-ray diffractogram and Fourier transmission infrared analyses, the solid electrolyte films were in an amorphous state and the coexistence of interaction between cation $\mathrm{NH}_{4}^{+}$ and the polymer structure agrees that the complex film was successfully prepared. The scanning electron microscope observations revealed that the films appeared to be rough, flat, and irregularly shaped surface. The highest ionic conductivity $(\sigma)$ of $3.16 \times 10^{-4} \mathrm{Scm}^{-1}$ was achieved at room temperature $(303 \mathrm{~K})$ for the sample containing $30 \mathrm{wt} \%$ ammonium nitrate.
\end{abstract}

Keywords: solution cast technique, solid polymer electrolyte, complexation, ionic conductivity

\section{Abstrak}

Elektrolit polimer pepejal poli(sodium 4-stirenasulfonat) sebagai polimer perumah dan ammonium nitrat sebagai dopan ionik telah dihasilkan menggunakan pelarut tunggal melalui teknik tuangan larutan. Merujuk kepada analisa difraktogram sinar-X dan inframerah transformasi Fourier, filem-filem elektrolit pepejal dihasilkan dalam keadaan amorfus dan pengkompleksan di antara kation $\mathrm{NH}^{4+}$ dan struktur polimer mengesahkan filem tersebut berjaya dihasilkan. Pemerhatian mikroskopi elektron imbasan mendedahkan filem-filem tersebut mempunyai permukaan yang kasar, rata dan wujudnya bentuk-bentuk yang tidak seragam pada permukaannya. Nilai tertinggi konduktiviti ionik $(\sigma)$ of $3.16 \times 10^{-4} \mathrm{Scm}^{-1}$ telah diperolehi pada suhu bilik (303K) bagi sampel yang mengandungi $30 \mathrm{wt} . \%$ ammonium nitrat.

Kata kunci: teknik tuangan larutan, elektrolit polimer pepejal, pengkompleksan, konduktiviti ionik

\section{Introduction}

Polymer electrolytes are the topic of exhaustive studies, to a certain extent because of their opportunity to be utilized as the electrolyte in all-solid-state batteries [1]. Briefly, an ionic salt (for example, ammonium nitrate (NH)) is dissolved in a solid host polymer like poly(sodium 4-styrenesulfonate) (PSS) to form the polymer electrolyte and may be prepared as crystalline, amorphous, and/or in both phases. Wright proposed the first documented idea to prepare the solid polymer electrolyte [2]. Since then, studies of this subject have been continuously performed until 
today, aiming to discover the potential material of SPEs especially for energy storage applications. In general, SPE is known to have insufficient performance at ambient temperature, which could be one of the drawbacks to their usefulness compared to the existing conventional liquid/hybrid electrolytes [3]. To this extent, numerous studies have been conducted to overcome this disadvantage and to enhance their room-temperature conductivity as well as mechanical properties through blending a variety of polymers [2-4], crosslinking [5], insertion of ceramic fillers [6], plasticization [7], and doping with ionic salts [8-14]. The result from these studies indicated that the utilization of doping salts, which formed at low-temperature eutectics with polymers, is one of the significant approaches to gain SPE with high ionic conductivity and at the same time could preserve their flexibility by controlling the amount of salt in the polymer.

PSS is used as a host polymer and NH as an ionic dopant in SPEs preparation. PSS is well known as an anionic polyelectrolyte [15]. It is obtained by the polymerization of an anionic surfactant, sodium styrene sulfonate. This polyelectrolyte can be dissolved in polar solvents as listed in Zoghlami et al. [15]. PSS gets exclusive awareness by many researchers because of its advantages as an agent of dispersion of graphene in water for sensor application [16], as filler for coating thin mercury film electrode, and as a detector to trace metal in water [17-20]. PSS also can act as an effective binder for graphene sheet, increase the specific capacitance, and improve the rate capability of capacitance [21]. It is universally used as a host polymer and, experimentally proven by some researchers, can boost the ionic conductivity in electrolyte systems [22-25].

$\mathrm{NH}$, the chemical compound with the formula $\mathrm{NH}_{4} \mathrm{NO}_{3}$, came with white crystalline solids at room temperature. It is odourless, easily soluble in hot and cold water, and highly soluble in acetone, partially soluble in methanol, and insoluble in diethyl ether. It is useful reagents in agriculture and military fields [26, 27]. Previous studies show that the polymers-based complex with NH possess high ionic conductivity, making these hybrids' membranes attractive for further exploration $[28,29]$.

In this current work, the authors attempt to study the effect of $\mathrm{NH}$ on the morphology, structural, and electrical properties of PSS. To examine the evolution of the morphology on the surface of doped-SPE, the SEM technique was used with high and low magnification configurations. The structure modifications of SPE were investigated through FTIR spectroscopy and X-ray diffraction, respectively. Their electrical properties were determined by electrochemical impedance spectroscopy.

\section{Preparation}

\section{Materials and Methods}

Membranes were prepared using a solution casting technique. The details of the compositions of the PSS (Aldrich, molecular weight $\sim 5 \times 10^{6}$ ) doped with NH (Sigma-Aldrich, 99.99\%) follow. Briefly, the solutions were obtained by diluting $1 \mathrm{~g}$ of PSS powder into $100 \mathrm{ml}$ of distilled water. Subsequently, different amounts of NH (varied from 0 to 30 in weight percentage, wt.\%) were added to the solutions, as listed in Table 1.

Table 1. The compositions of PSS and NH powders.

\begin{tabular}{lcccc}
\hline & $\begin{array}{c}\text { Solvent } \\
(\mathbf{m l})\end{array}$ & $\begin{array}{c}\text { Polymer } \\
(\mathbf{g})\end{array}$ & $\begin{array}{c}\text { Ionic Salt } \\
\text { (wt.\%) }\end{array}$ & $\begin{array}{c}\text { Ionic Salt } \\
(\mathbf{g})\end{array}$ \\
\hline Pure & 100 & 1 & 0 & 0 \\
A & 100 & 1 & 5 & 0.053 \\
B & 100 & 1 & 10 & 0.111 \\
C & 100 & 1 & 15 & 0.177 \\
D & 100 & 1 & 20 & 0.250 \\
E & 100 & 1 & 25 & 0.333 \\
F & 100 & 1 & 30 & 0.429 \\
\hline
\end{tabular}


The mixtures were stirred continuously with the magnetic stirrer until homogenous solutions were achieved. Next, the solutions were poured into different plastic Petri dishes and left for the evaporation process to form thin films. The films were then kept in desiccators (with silica gel) for a certain period to reduce water content. All the experimental steps were carried out at room temperature.

\section{Characterization}

The amorphous or crystal phase of a sample was determined by X-ray diffraction technique. XRD is also used to analyse the atomic arrangements of the materials, because inter-planar spacing ( $d$-spacing) of the diffracting planes is the same order of X-ray wavelength. A MiniFlex II diffractometer equipped with an X'celerator using $\mathrm{CuK} \alpha$ radiation was used to record the XRD pattern in the range of $2 \theta=10^{\circ}$ to $80^{\circ}$.

The composition and complex formation in the sample was analysed by a Thermo Nicolet Avatar 380 FT-IR spectrometer. It simultaneously collects spectral data in a wide spectral range from 4000 to $675 \mathrm{~cm}^{-1}$ with spectra resolution of $4 \mathrm{~cm}^{-1}$. The spectrometer is equipped with an attenuated total reflection (ATR) accessory with a germanium crystal. The sample was put on the germanium crystal and infrared light was passed through the sample; the graph is sketched.

The surface morphology of the prepared sample was investigated by scanning electron microscopy. It was carried out using the Model JEOL JSM-6360LA device with an acceleration voltage of $20 \mathrm{kV}$. The samples were observed under the magnifications of $300 \mathrm{x}$ to $5000 \mathrm{x}$, accordingly. Through this technique, the crystalline or amorphous nature of the sample can be directly observed. Impedance spectroscopes for room temperature $\left(30{ }^{\circ} \mathrm{C}\right)$ were measured by using the HIOKI 3532-02 LCR Hi-Tester, which is interfaced to a computer. It is used to determine the electrical properties over a wide range of frequencies from $50 \mathrm{~Hz}$ to $1 \mathrm{MHz}$. The prepared samples were cut into two-centimetre diameter size and placed between two stainless steel electrodes on a sample holder connected via leads to a computer. The imaginary impedance $\left(Z_{i}\right)$ versus the real impedance $\left(Z_{r}\right)$ was plotted using the same scale for both vertical and horizontal axes to obtain the bulk resistance, $R_{b}$. A micrometre-screw gauge was used to measure the sample thickness, employed to calculate conductivity of the sample using the equation (1):

$$
\sigma=\frac{t}{R_{b} A}
$$

where $t=$ thickness of the thin film (in $\mathrm{cm}$ ) and $A=$ area of the contact and $R_{b}=$ bulk resistance.

\section{Results and Discussion}

The results of XRD analysis at room temperature recorded from $2 \theta=10^{\circ}$ to $80^{\circ}$ for NH, pure PSS, and PSS-NH complexes systems are shown in Figure 1. Several sharp peaks, located at 22.2, 24.1, 28.6, 32.7, 35.9, 37.6, 39.9, $45.6,49.3,50.8,51.5$, and $58.4^{\circ}$, were clearly visible in the $\mathrm{NH}$ pattern, indicating that it is rich with crystalline moieties. A hump (very broad) peak can be observed in between $25^{\circ}$ and $35^{\circ}$, which also corresponds to an amorphous phase of $\mathrm{NH}$; however, its portion is quite low compared to the crystalline phase, although these structures of NH are similarly reported in literature [30-34]. As the comparison for all XRD patterns of PSS-NH samples reveal that they have a certain similarity and subsist in an amorphous state. Specifically, a very broadened peak in between $2 \theta=15^{\circ}$ and $25^{\circ}$ can be identified in PSS diffraction pattern, which refers to naturally amorphous phases of polymer. By adding 10 to $30 \mathrm{wt} . \% \mathrm{NH}$ into the polymer, two hump peaks are observed in the patterns located at $15^{\circ}$ to $25^{\circ}$ and $23^{\circ}$ to $33^{\circ}$, which match the broaden peaks of PSS and NH, respectively, and confirm the complex processes taking place in these materials. The result also reveals that the complex films tend to be highly amorphous rather than crystalline phase, and, significantly, the presence of NH does not have much influence on the formation of peaks in the complex samples. The coexistence of XRD peaks belongs to these two materials, validating their appearance in solid polymer electrolyte film $[35,36]$.

The FTIR spectra for ammonium nitrate and polymer-ionic dopant complexes are shown in Figure 2. In the spectrum of NH (Figure 2(a)), the strong and medium bands of NH at 1380 and $832 \mathrm{~cm}^{-1}$ correspond to the nitrate functional group [37, 38]. Another band in the nitrate group is $1630 \mathrm{~cm}^{-1}$, where the water molecule is bound symmetrically or asymmetrically to the nitrate ion, according to Goebbert et al. [39]. The spectrum also contains a band at $3030 \mathrm{~cm}^{-1}$ that is due to the $\mathrm{N}-\mathrm{H}$ stretching in the ammonium group. From observation on the complexed 
spectra, there are significant changes for all prepared samples, especially within their intensity and spectrum patterns. Ordinarily, the peak intensities increase as the used amount of NH in PSS increases, and, specifically, the characteristic peaks of NH peaks obviously appear in the whole of the PSS spectra. Coates and John mentioned that if an IR spectrum has the functional group of two different materials (in this case, ammonium nitrate and PSS), it can confirm that the chain-reaction (or addition) polymerization process is successfully achieved due to the existence of each chain in that spectrum [37].

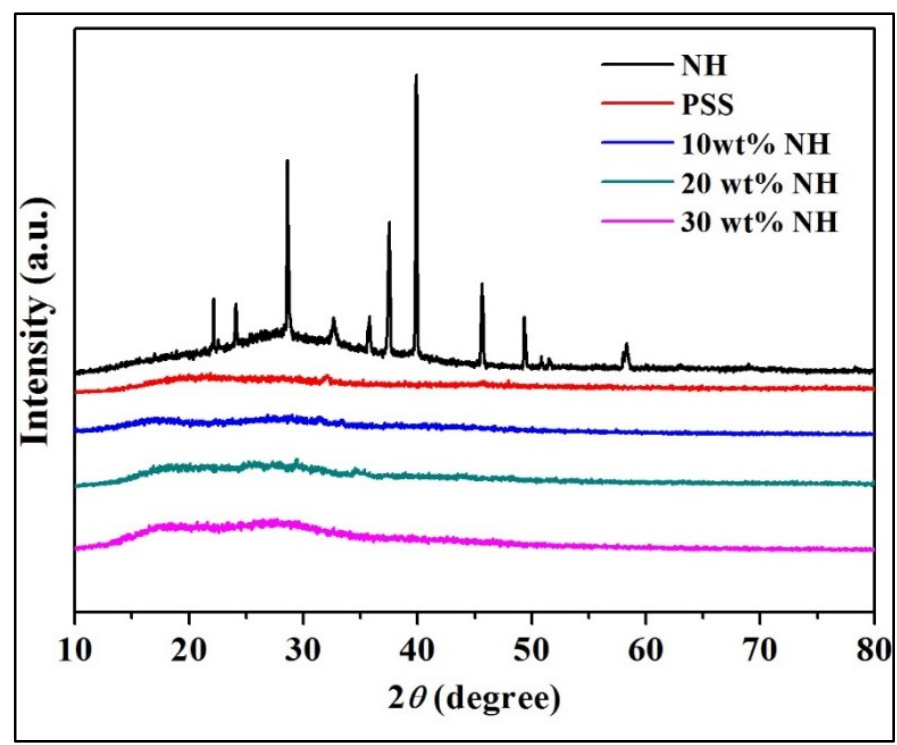

Figure 1. XRD pattern for PSS, NH, and hybrid PSS-NH films
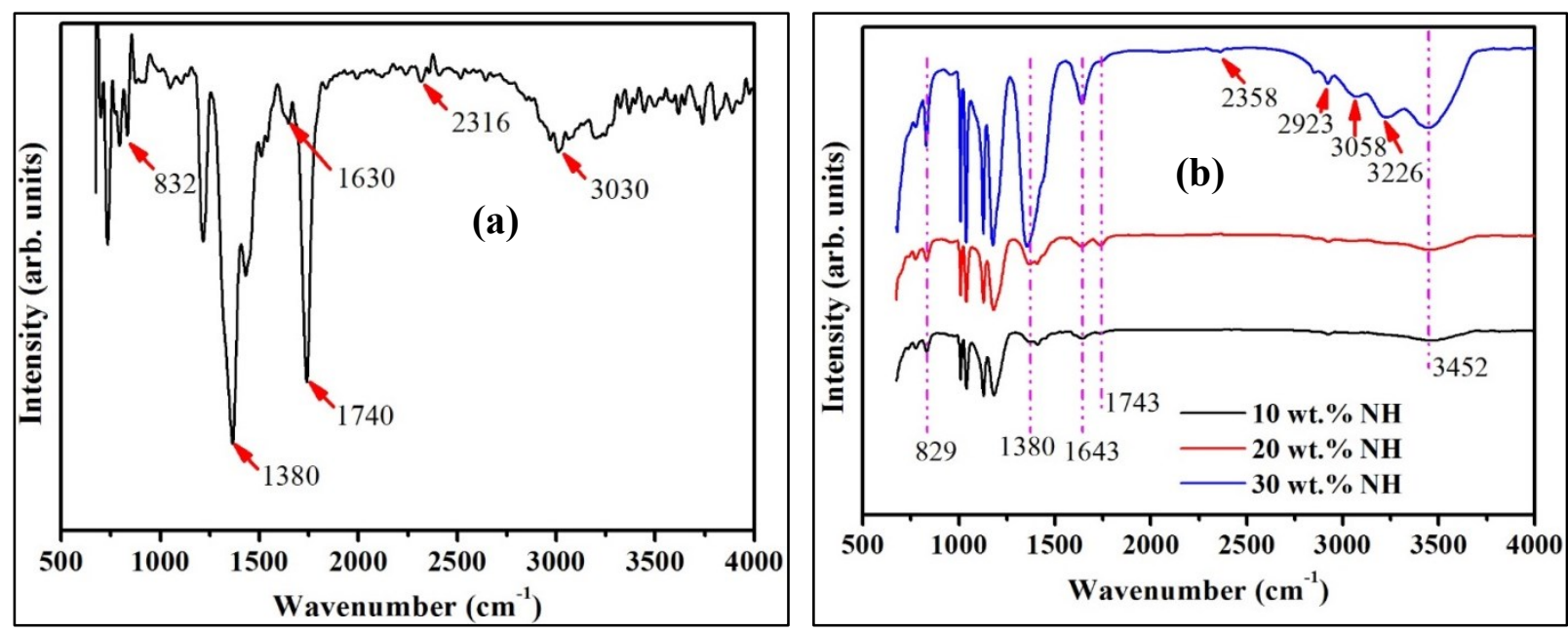

Figure 2. FTIR analysis of (a) NH and (b) different weight \% of NH in PSS

Figure 3 shows the scanning electron micrographs of pure PSS and PSS-NH complex films. Typically, all prepared samples were transparent films with no separation. They were in a solid form while analysed at different magnifications $(\times 300 ; \times 500 ; \times 5,000)$ and regions, as shown in Figures 3(a) to 3(f). In Figure 3(a), the morphology of $\mathrm{NH}$ powder appeared to be uneven, rough, and contain some irregular shapes with varied sizes, whereas Figure 
3(b) is the morphology of PSS powder, indicating that PSS particles have the most regular shape and smoothest surface texture (closer to spheres with a smoother surface). Figure 3(c) illustrates the SEM image for the pure PSS film with some of wave shape observed on its surface. The wave shape, together with some small grains contour (x5000 magnification image), were also observed on the whole SEM image for $10 \mathrm{wt} . \% \mathrm{NH}$ sample (Figure 3(d)). The surface contour of the sample with $20 \mathrm{wt} . \% \mathrm{NH}$ changed to have a bigger and thicker wave shape, as depicted in Figure 3(e). Taken in a selected area of the image, the morphology tended to have some mixed small and large square plate grain shapes. These square plate grains appeared in a larger size (compared to Figure 3(d)) and presented in a different directional orientation. Figure 3(f) demonstrates the SEM image of the sample containing 30 wt. \% NH. Adding a stated amount of $\mathrm{NH}$ shows that the morphology surface has changed a little bit with the existence of many smaller diameters of wave contours covering the whole area of the SEM image. Interestingly, the zooming SEM image at 5000x magnification reveals that this surface morphology has similar grains shapes as observed in Figure 3(d), but with most them at a smaller size, and their directional orientation is more arranged.

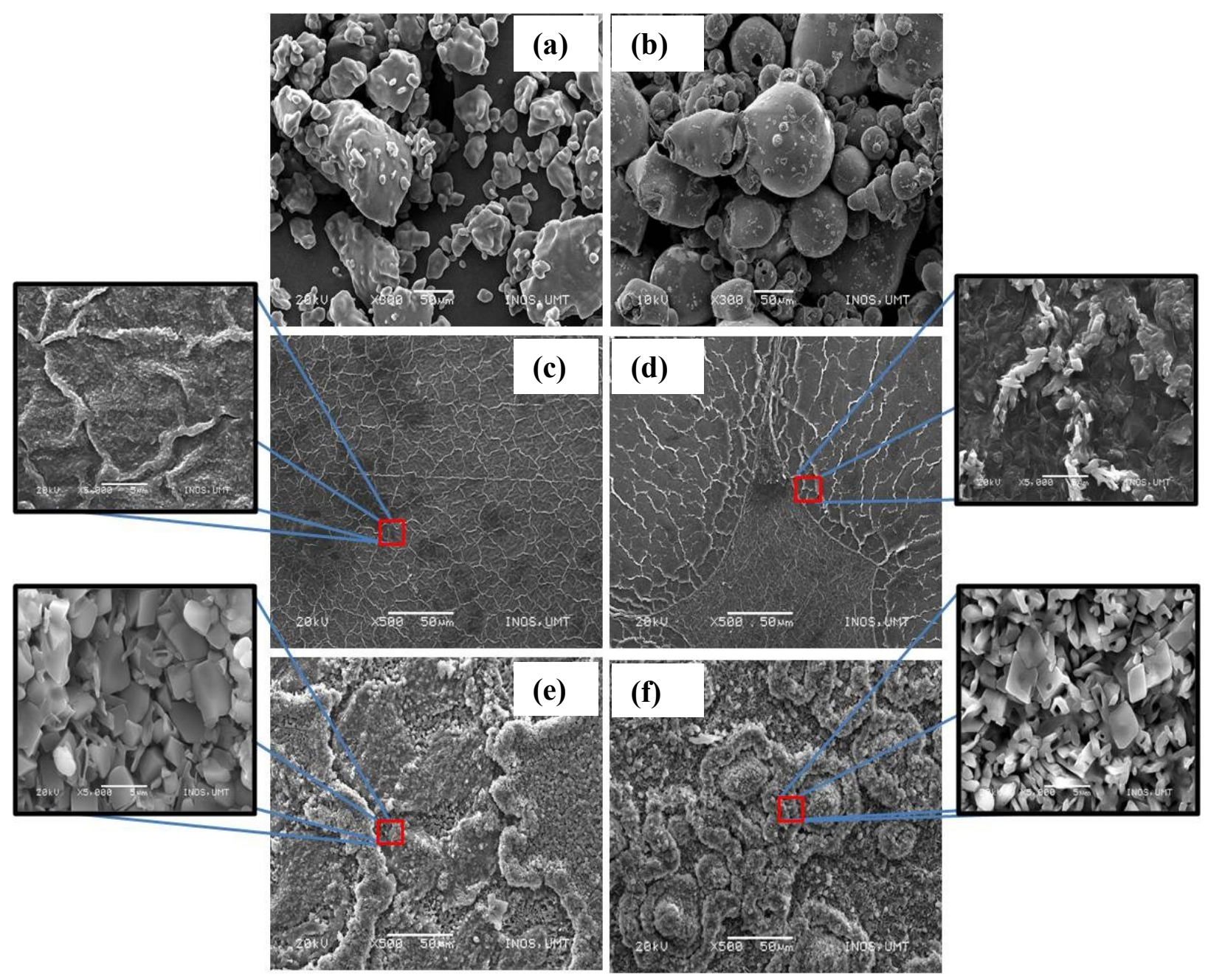

Figure 3. SEM micrographs for (a) NH powder, (b) PSS powder, (c) PSS film (pure), (d) 10 wt.\% NH (sample B), (e) $20 \mathrm{wt} . \% \mathrm{NH}$ (sample D) and (f) $30 \mathrm{wt} . \% \mathrm{NH}$ (sample F). (Note: $\square$ : the selected image in $\mathrm{x} 5000$ magnification)

The specific size of surface area for selected grains for Figure 3(e) and Figure 3(f) was calculated using imaging software and depicted in Figure 4. The measured data were transformed to the graph of area versus the grain number 
Mohd Faiz et al: ION-CONDUCTING POLYMER ELECTROLYTE FILMS BASED ON POLY (SODIUM 4STYRENESULFONATE) COMPLEXED WITH AMMONIUM NITRATE: STUDIES BASED ON MORPHOLOGY, STRUCTURAL AND ELECTRICAL SPECTROSCOPY

(Figure $4 \mathrm{~b}$ and Figure $4 \mathrm{~d}$ ). As observed, the mixed grains with the biggest and average area sizes in $20 \mathrm{wt} . \% \mathrm{NH}$ are 19.8 and $5.1 \mu \mathrm{m}^{2}$, whereas for the sample with $30 \mathrm{wt} . \% \mathrm{NH}$, the values are 9.7 and $3.8 \mu \mathrm{m}^{2}$, respectively. A group of researchers have proven that the size of particle can provide a significant effect on the electrical properties of materials when employed in the closed system [40-42].


Figure 4. The area size of grain for $(a, b)$ sample e and $(c, d)$ sample $f$

Figure 5 shows the SEM image for the sample of $30 \mathrm{wt} . \% \mathrm{NH}$, with red circles of pores detected in the whole image. There are two differences of images in Figure 4 and Figure 5: first, the area size of grains, and second, the structure, which came together with the pores distinguished in the specific area of the image. These pores have the diameter size in range of 14 to $38 \mathrm{~nm}$, as tabulated in Table 2, and have special characteristics which could contribute to enhancing the electrical properties of the studied materials $[43,44]$. 


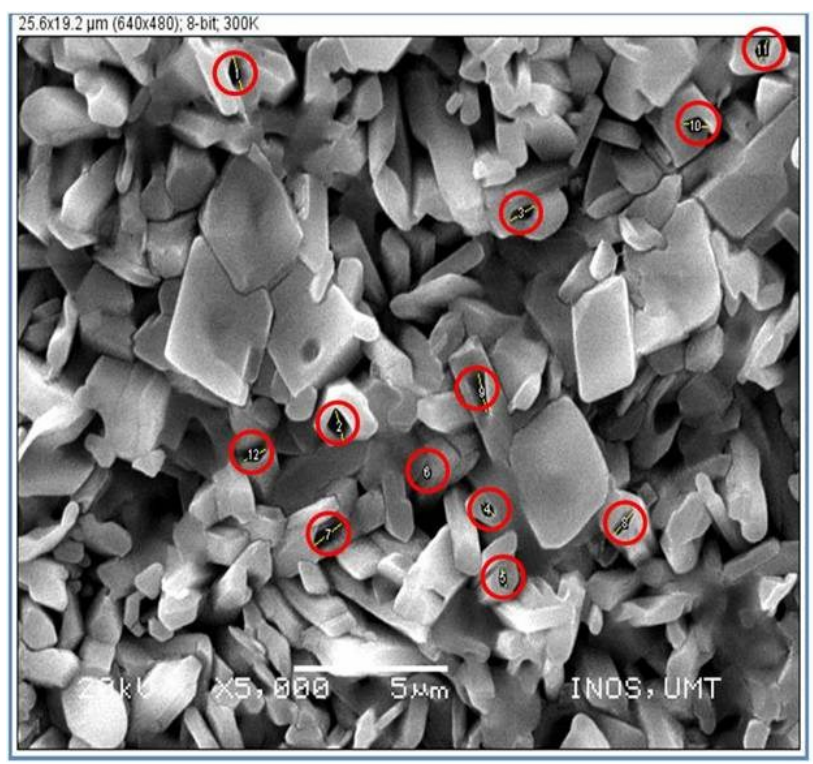

Figure 5. The SEM image of pore in the specific location in the whole SEM image for the highest conductivity sample

Table 2. The diameter of pore in nanometre

\begin{tabular}{lc}
\hline No. of Pore & Pore Diameter (nm) \\
\hline 1 & 38 \\
2 & 35 \\
3 & 35 \\
4 & 21 \\
5 & 21 \\
6 & 14 \\
7 & 38 \\
8 & 35 \\
9 & 35 \\
10 & 21 \\
11 & 21 \\
12 & 14 \\
\hline
\end{tabular}

The values of bulk resistance, $R_{b}$, and the conductivity, $\sigma$, of the samples are tabulated in Table 3 . The measured thicknesses of the samples were between 0.009 and $0.016 \mathrm{~cm}$. The bulk resistance of pure PSS in the film form is about $1.01 \times 10^{3} \Omega$, with an ionic conductivity of approximately $2.83 \times 10^{-6} \mathrm{~S} \mathrm{~cm}^{-1}$. By adding $5 \mathrm{wt} \%$ of NH in the polymer, the bulk resistance increases to $1.21 \times 10^{3} \Omega$ and the ionic conductivity increases to $3.68 \times 10^{-6} \mathrm{~S} \mathrm{~cm}^{-1}$. The bulk resistance $\left(1.08 \times 10^{2} \Omega\right)$ decreases after adding $15 \mathrm{wt} . \% \mathrm{NH}$ and gives the ionic conductivity of $1.85 \times 10^{-5} \mathrm{~S}$ $\mathrm{cm}^{-1}$. Further adding 20 wt.\% NH, the bulk resistance increases to $1.82 \times 10^{3} \Omega$ and gives the lowest ionic conductivity $\left(8.05 \times 10^{-6} \mathrm{~S} \mathrm{~cm}^{-1}\right)$. At $25 \mathrm{wt} . \% \mathrm{NH}$, the measured resistance decreases $\left(3.48 \times 10^{3} \Omega\right)$, offering an increase in ionic conductivity to $1.46 \times 10^{-5} \mathrm{~S} \mathrm{~cm}^{-1}$. The increase trend of ionic conductivity continues in the 30 wt.\% NH sample, with the value of $3.16 \times 10^{-4} \mathrm{~S} \mathrm{~cm}^{-1}$. Additional $\mathrm{NH}$ in the polymer solution experimentally reduces rigidity of the mixture; as a result, the complex film cannot be formed, and its ionic conductivity is difficult 
to measure using the current equipment. The overall trend of conductivity variation as a function of salt content at room temperature is depicted in Figure 6. In general, the increasing trend of ionic conductivity is probably due to the amorphous state of film and the increase in the number of mobile charge carriers, as the $\mathrm{NH}$ concentration increases in the samples. The decreasing pattern here is possibly due to the decrease in carrier mobility and the crystallites affecting ionic conductivity. The boundary between the crystallites and the amorphous area could function as a barrier for the ionic migration. The crystallites also sterically hinder the ionic migration. These effects may be answerable for the lower ionic conductivity for the film at $20 \mathrm{wt} . \%$ concentration [45-48]. The low crystalline phase and the presence of porosity structure should contribute more to enhancing the ionic conductivity by allowing the larger group of ions to flow through it $[1,45,48]$.

Table 3. The ionic conductivity of PSS-NH at room temperature

\begin{tabular}{lcc}
\hline & $\begin{array}{c}\text { Bulk resistance, } \\
\boldsymbol{R}_{\boldsymbol{b}}(\boldsymbol{\Omega})\end{array}$ & $\begin{array}{c}\text { Conductivity, } \boldsymbol{\sigma} \\
\left(\mathbf{S c m}^{-1}\right)\end{array}$ \\
\hline Pure & $1.01 \times 10^{3}$ & $2.83 \times 10^{-6}$ \\
A & $1.21 \times 10^{3}$ & $3.68 \times 10^{-6}$ \\
B & $1.08 \times 10^{2}$ & $2.35 \times 10^{-5}$ \\
C & $1.03 \times 10^{2}$ & $1.85 \times 10^{-5}$ \\
D & $1.82 \times 10^{3}$ & $8.05 \times 10^{-6}$ \\
E & $3.48 \times 10^{2}$ & $1.46 \times 10^{-5}$ \\
F & $1.61 \times 10^{1}$ & $3.16 \times 10^{-4}$ \\
\hline
\end{tabular}

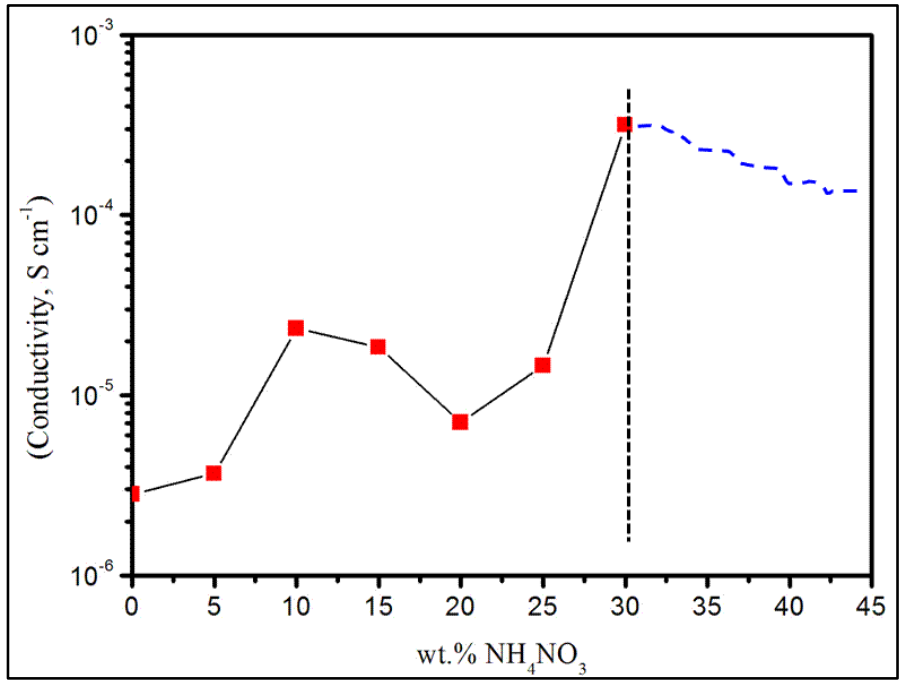

Figure 6. The conductivity variation as a function of salt content at room temperature

\section{Conclusion}

In this study, the ion-conducting polymer electrolytes based on PSS-NH have been successfully prepared via a solution casting technique. The effects of NH on the PPS structure were investigated based on X-ray diffraction, infrared spectroscopy, and scanning electron microscope. To current knowledge, this is the first time that the film based on PSS complex with NH has been discussed, particularly regarding its structure and ionic conductivity. This information is crucial for further studies on thin film electrolytes as one of the key components in solid state battery application. 
In summary, it can be concluded that the complex films were in the amorphous rather than the crystalline phase. The FTIR analysis can be described as coexistence bands from both materials, which confirmed the successful polymerization process occurring in this study. According to the morphology observations, the addition of NH can appreciably change the surface morphology of the film, with the highest conducting sample containing $30 \mathrm{wt} . \% \mathrm{NH}$ $\left(1.82 \times 10^{-5} \mathrm{~S} \mathrm{~cm}^{-1}\right)$ tending to have mixed small and large square uneven shapes that attached together. Also observed, with an addition of $30 \mathrm{wt} . \% \mathrm{NH}$ to PSS film, the pore structures can be clearly seen, which the authors strongly believe contributed in enhancing the ionic conductivity of the PSS-NH hybrids film.

\section{Acknowledgement}

The authors would like to thank the School of Fundamental Science and School of Ocean Engineering, Universiti Malaysia Terengganu for financial supports on this study.

\section{References}

1. Gadjourova, Z., Andreev, Y. G., Tunstall, D. P. and Bruce, P. G. (2001). Ionic conductivity in crystalline polymer electrolytes. Nature, 412: 520-523.

2. Wright, P. V. (1975). Electrical conductivity in ionic complexes of poly(ethylene oxide). British Polymer Journal, 7:319-324.

3. Dillip, K. P., Choudhary, R. N. P. and Samantaray, B. K. (2008). Studies of dielectric relaxation and AC conductivity behaviour of plasticized polymer nanocomposite electrolyte. International Journal Electrochemistry Science, 3: 597-608.

4. Kim, D. W., Park, J. R. and Rhee, H. W. (1996). Conductivity and thermal studies of solid polymer electrolytes prepared by blending poly(ethylene oxide), poly(oligo[oxyethylene]oxysebacoyl) and lithium perchlorate. Solid State Ionics, 83(1-2): 49-56.

5. Wieckzorek, W. and Stevens, J. R. (1997). Impedance spectroscopy and phase structure of polyetherpoly(methyl methaacrylate)- $\mathrm{LiCF}_{3} \mathrm{SO}_{3}$ blend-based electrolytes. Journal of Physical Chemistry B, 101(9):15291534.

6. Przyluski, J. and Wieczorek, W. (1989). Increasing the conductivity of polymer solid electrolytes: A review. Solid State Ionics, 36(3-4): 165-169.

7. Cherng, J. Y., Munshi, M. Z. A., Owens, B. B. and Smyrl, W. H. (1988). Applications of multivalent ionic conductors to polymeric electrolyte batteries. Solid State Ionics, 28-30: 857-861.

8. Hassan, M. F. and Arof, A. K. (2005). Ionic conductivity in PEO-KOH polymer electrolytes and electrochemical cell performance. Physica Status Solidi-A, 202(13): 2494-2500.

9. Rajendran, S., Sivakumar, M. and Subadevi, R. (2004). Investigations on the effect of various plasticizers in PVA-PMMA solid polymer blend electrolytes. Materials Letters, 58(5), 641-649.

10. Choi, N. S. and Park, J. K. (2001). New polymer electrolytes based on PVC/PMMA blend for plastic lithiumion batteries. Electrochimica Acta, 46(10-11): 1453-1459.

11. Pandey, K., Dwivedi, M. M., Asthana, N., Singh, M. and Agrawal, S. L. (2011). Structural and ion transport studies in (100-x)PVdF + xNH4SCN gel Electrolyte. Materials Sciences and Application, 2: 721-728.

12. Zhang, J., Huang, X., Fu, J., Huang, Y., Liu, W. and Tang, X. (2010). Novel PEO-based composite solid polymer electrolytes incorporated with active inorganic-organic hybrid polyphosphazene microspheres. Materials Chemistry and Physics, 121(3): 511-518.

13. Feng, W., Wang, J. and $\mathrm{Wu}, \mathrm{Q}$. (2005). Preparation and conductivity of PVA films composited with decatungstomolybdovanadogermanic heteropoly acid. Materials Chemistry and Physics, 93(1): 31-34.

14. Ramesh, S. and Ng, H. M. (2011). An investigation on PAN-PVC-LiTFSI based polymer electrolytes system. Solid State Ionics, 192(1): 2-5.

15. Zoghlami, O., Guettari, M. and Tajouri, T. (2017). Study of poly(sodium-4-styrenesulfonate) behavior in water/non-solvent mixtures by conductivity and refractive index measurements. Colloid and Polymer Science, 295(9): 1729-1739.

16. Li, J., Miao, D., Yang, R., Qu, L. and Harrington, P. B. (2014). Synthesis of poly(sodium 4-styrenesulfonate) functionalized graphene/cetyltrimethylammonium bromide (CTAB) nanocomposite and its application in electrochemical oxidation of 2,4-dichlorophenol. Electrochimica Acta, 125: 1-8. 
17. Monterroso, S. C., Carapuca, H. M. and Dearte, A. C. (2003). Performance of poly(styrenesulfonate)-coated thin mercury film electrodes in the determination of lead and copper in estuarine water samples of high salinity. Electroanalysis, 15(23-24): 1878-1883.

18. Jia, J., Cao, L., Wang, Z. and Wang, T. (2007). Properties of poly(sodium 4-styrenesulfonate)-ionic liquid composite film and its application in the determination of trace metals combined with bismuth film electrode. Electroanalysis, 20: 542-549.

19. Rocha, L. S., Pinheiro, J. P. and Carapuca, H. M. (2006). Ion-exchange voltammetry with nafion/poly(sodium 4-styrenesulfonate) mixed coatings on mercury film electrodes: characterization studies and application to the determination of trace metals. Langmuir, 22(19): 8241-8247.

20. Du, F. P., Wang, J. J., Tang, C. Y., Tsui, C. P., Zhou, X. P., Xie, X. L. and Liao, Y. G. (2012). Water-soluble graphene grafted by poly(sodium 4-styrenesulfonate) for enhancement of electric capacitance. Nanotechnology, 23: 475704 .

21. Imrea, A. W., Schönhoff, M. and Cramer, C. (2008). A conductivity study and calorimetric analysis of dried poly(sodium 4-styrene sulfonate)/poly(diallyldimethylammonium chloride) polyelectrolyte complexes. The Journal of Chemical Physics, 128: 134905.

22. Wesp, V., Hermann, M., Schäfer, M., Hühn, J., Parak, W. J. and Weitzel, K. M. (2016). Bombardment induced ion transport - part IV: Ionic conductivity of ultra-thin polyelectrolyte multilayer films. Physical Chemistry Chemical Physics, 18(6): 4345-4351.

23. Kolling, T., Schlemmer, A., Pietzonka, C., Harbrecht, B. and Weitzel, K. M. (2010). Field effects in alkali ion emitters: Transition from Langmuir-Child to Schottky regime. Journal of Applied Physics, 107: 014105.

24. Schulze, S., Zakel, J., Schäfer, M. and Weitzel, K. M. (2012). Potassium ion transport through poly-paraxylylene films. IEEE Transactions on Dielectrics and Electrical Insulation, 19: 1167-1174.

25. Overberger, C. G. and Sannes, K. N. (1974). Polymere als reagentien fur organische synthesen. Angewandte Chemie, 86: 139-145.

26. Cook, M. A. and Talbot, E. L. (1951). Explosive sensitivity of ammonium nitrate-hydrocarbon mixtures. Industrial and Engineering Chemistry, 43(5): 1098-1102.

27. Majid, S. R. and Arof, A. K. (2005). Proton-conducting polymer electrolyte films based on acetate complexed with $\mathrm{NH}_{4} \mathrm{NO}_{3}$ salt. Physica $B, 355(1-4)$ : 78-82.

28. Kamarudin, K. H. and Isa, M. I. N. (2013). Structural and DC ionic conductivity studies of carboxy methylcellulose doped with ammonium nitrate as solid polymer electrolytes. International Journal of Physical Sciences, 8(31): 1581-1587.

29. Hendricks, S. B., Posnjak, E. and Kracek, F. C. (1932). Molecular rotation in the solid state. The variation of the crystal structure of ammonium nitrate with temperature. Journal of American Chemical Society, 54: 2766-2786.

30. Ferg, E. E., Levendis, D. C. and Schoening, F. R. L. (1993). X-ray diffraction study of the orientational relation between the IV and III phases of ammonium nitrate. Chemistry of Materials, 5(9): 1293-1298.

31. Sorescu, D. C. and Thompson, D. L. (2001). Quantum mechanical studies of pressure effects in crystalline ammonium dinitramide. Journal of Physical Chemistry A, 105(31): 7413-7422.

32. Wu, H. B., Chan, M. N. and Chan, C. K. (2007). FTIR characterization of polymorphic transformation of ammonium nitrate. Aerosol Science and Technology, 41(6): 581-588.

33. Golovina, N., Nechiporrenko, G., Nemtsev, G., Zyuzin, I., Manelis, G. B. and Lempert, D. (2009). Ammonium nitrate phase state stabilization with small amounts of some organic compounds. Central European Journal of Energetic Materials, 6: 45-56.

34. Joshi, J. M. and Sinha, V. K. (2006). Synthesis and characterization of carboxymethyls chitosan grafted methacrylic acid initiated by ceric ammonium nitrate. Journal of Polymer Research, 13: 387-395.

35. Parvathy, P. C. and Jyothi, A. N. (2012). Synthesis, characterization and swelling behavior of superabsorbent polymers from cassava starch-graft-poly(acrylamide). Starch, 64: 207-218.

36. Coates, J. (2000). Interpretation of infrared spectra, a practical approach. in encyclopedia of analytical chemistry, Meyers, R. A., Editor. Chichester: John Wiley \& Sons Ltd.

37. Miller, F. A. and Wilkins, C. H. (1952). Infrared spectra and characteristic frequencies of inorganic ions. Analytical Chemistry, 24: 1253-1294. 
38. Goebbert, D. J., Garand, E., Wende, T., Bergmann, R., Meijer, G., Asmis, K. R. and Neumark, D. M. (2009). Infrared spectroscopy of the microhydrated nitrate ions $\mathrm{NO}_{3}^{-}\left(\mathrm{H}_{2} \mathrm{O}\right)_{1-6}$. Journal of Physical Chemistry A, 113(26): 7584-7592.

39. Suherman, H., Duskiardi and Irmayani. (2015). Effect of particle size and graphite loading concentration on the electrical conductivity of graphite/epoxy composites. Paper presented at the International Conference on Chemical, Metallurgy and Material Science Engineering (CMMSE-2015), Pataya, Thailand.

40. Tsujimoto, Y., Matsushita, Y., Yu, S., Yamaura, K. and Uchikoshi, T. (2015). Size dependence of structural, magnetic, and electrical properties in corundum-type $\mathrm{Ti}_{2} \mathrm{O}_{3}$ nanoparticles showing insulator-metal transition. Journal of Asian Ceramic Societies, 3(3): 325-333.

41. Supmak, W., Petchsukand, A. and Thanaboonsombut, A. (2008). Influence of ceramic particle sizes on electrical properties of lead zirconate titanate (pzt)/nylon57 composites. Journal of Metals, Materials and Minerals, 18: 147-151.

42. Li, B. Q. and Lu, X. (2011). The effect of pore structure on the electrical conductivity of Ti. Transport in Porous Media, 87(1): 179-189.

43. Li, Y., Samad, Y. A., Polychronopoulou, K., Alhassan, S. M. and Liao, K. (2014). Highly electrically conductive nanocomposites based on polymer-infused graphene sponges. Scientific Reports, 4: 4652.

44. Angell, C. A. (1992). Mobile ions in amorphous solids. Annual Reviews of Physics Chemistry, 43: 693-717.

45. Tuller, H. (2007). Ionic conductivity and applications. Springer Handbook of Electronic and Photonic Materials.

46. Feng S, Greenblatt M. (1992). Preparation, characterization and ionic conductivity of novel crystalline, microporous germanates, $\mathrm{M}_{3} \mathrm{HGe}_{7} \mathrm{O}_{16} \cdot \mathrm{xH}_{2} \mathrm{O}, \mathrm{M}=\mathrm{NH}^{4+}, \mathrm{Li}^{+}, \mathrm{K}^{+}, \mathrm{Rb}^{+}, \mathrm{Cs}^{+} ; \mathrm{x}=4-6$. II. Chemistry of Materials, 4(2):462-468.

47. Kim, D. W., Ryoo, B. K., Park, J. K., Maeng, K. S. and Hwang, T. S. (1992). Study on the ionic conductivity and mobility of liquid polymer electrolytes containing lithium salts. Polymer Journal, 24: 509-518.

48. Braga, M. H., Murchison, A. J., Ferreira, J. A., Singh, P., \& Goodenough, J. B. (2016). Glass-Amorphous Alkali-Ion Solid Electrolytes and Their Performance in Symmetrical Cells, In: Energy and Environmental Science. Energy and Environmental Science, 9(3): 948-954. 